\title{
Effects of Alligator Pepper (Aframomum Melegueta) Meal Additive Diets on Growth ANS Feed Utilization Clarias Gariepinus (Burchell, 1822)
}

\author{
Kwankwa, T., Ityumbe, M.S., Ndumari, N.P., Garba, T.H., Habib, M., Usman, A, \\ Sogbesan, O.A* \\ Department of Fisheries, Modibbo Adama University of Technology, Yola
}

*Corresponding Author: Sogbesan, O.A, Department of Fisheries, Modibbo Adama University of Technology, Yola.

\begin{abstract}
The need to boost fish immunity and enhance their growth was a key tool in aquaculture development. A semi-flow through system was used to conduct the performance of Clarias gariepinus fingerlings fed Alligator Pepper (Aframomum Melegueta) meal additive diets. Three Hundred (300) Clarias gariepinus fingerlings of mean weight, $3.2 \pm 0.11 \mathrm{~g}$ and length $7.30 \pm 0.80 \mathrm{~cm}$ were acclimatized and stocked at Twenty (20) fingerlings per tanks. All diets prepared were $40.00 \%$ crude protein. Different levels of alligator pepper were included at T1 0.00\%, T2 1.50\%, T3 3.00\%, T4 4.50\% and T5 6.00\%. Each treatment was in triplicate using 20 Clarias gariepinus fingerlings of about $3.00 \pm 0.05 \mathrm{~g}$. The fingerlings were fed $5 \%$ body weight per day divided equally in two-parts, morning and evening for 12 weeks. Data generated were analyzed using ANOVA. The result of the experiment showed that lowest mean weight gain (MWG) (5.89) was in diet $T 1$ and $T 5$ recorded the highest mean weight gain of $10.59 \mathrm{~g}$. The highest specific growth rate was in T5 with $0.7744 \%$ while the lowest is T1 with 0.5446\%. Protein Efficiency Ratio (PER), 1.92 was highest at Tland $T 2$ the lowest with 0.962. The temperature, dissolved oxygen and $\mathrm{pH}$ were not significantly different $(p<0.05)$ but there was significant difference $(p<0.05)$ in the Ammonia concentration with the treatments. Based on the results from these findings, Alligator pepper meal additive diet is recommended at a range of $3.0-6.0 \mathrm{~g} / 100 \mathrm{~g}$ of diet for sustainable fish production.
\end{abstract}

Keywords: Growth, Feed utilization, Alligator pepper, Additive, Clarias gariepinus.

\section{INTRODUCTION}

Aquaculture is a fast growing agricultural business in Nigeria which focused on provision of fish to compliment the one from the wild which had increase human demand for fish due to high population growth according to Spinelli (2007). Nutritionists have been evaluating alternative sources of aquaculture diets to supplement the conventional ingredients (|Sogbesan, 2014) while some had reported various additives to promote growth and other performances as documented by Sogbesan $e t$ al. (2017).

Plants provide not only essential nutrients needed for life, but also other bioactive phytochemicals that contribute to health promotion and disease prevention while the macro- and micronutrients in plants were long thought to be one of the essential components for fish health. Some of these plants include pepper fruit (Dennettia tripetala), garlic (Allium sativum), alligator pepper (Aframomum melegueta), Basil leaf (Ocimum gratissimum), and kola nut (Cola nitida) (Mclaughlin et al., 1991). Extracts from the seeds of Aframomum melegueta have potent antiseptic, fungicidal, antivirus and bactericidal properties, and have, therefore, been used in preventions of infections and treating wounds (Okwu, 2005) and in food from knowing the benefit and antibacterial properties. Alligator pepper has also been used for consumption and medicinal purposes because of its anti-oxidizing, antimicrobial, aphrodisiac, anti-inflammatory, analgesic, stimulating and digestive properties, and for treating gastrointestinal disorders (Alaje et al., 2014; Doherty et al., 2010). The seeds can be crushed and used for preparing concoctions for treating and healing wounds and for dermatological care. It is also believed to have purgative, galactagogue, anti-helmintic and hemeostatic properties and also very effective against schistosomiasis (Doherty et al., 2010; Igwe et al., 1999). 
The rearing of the Clarias gariepinus in Africa started in the early 1970s; it can be raised in high densities resulting in high net yields. It matures and relatively easily reproduces in captivity. Haruna (2010) reported that Clarias gariepinus is an opportunistic feeder, feeding on whatever is available in its habitat and shows a seasonal gonadal maturation which is usually associated with the rainy seasons. The study was to determine effects of alligator pepper (Aframomum melegueta) meal additive diets on growth and feed utilization Clarias gariepinus (Burchell, 1822) fingerlings.

\section{Materials And Methods}

\subsection{Experimental Location}

The experiment was carried out at Teaching and Research Fish Farm, Department of Fisheries, Modibbo Adama University of Technology, Yola. The experiment lasted for 12 weeks. The experiment was sited in Yola, Adamawa State Nigeria, inside Modibbo Adama University of Technology, Yola. Adamawa State lies between Latitudes $7^{\circ} \mathrm{N}$ and $11^{\circ} \mathrm{N}$ of the Equator and Longitude $11^{\circ} \mathrm{N}$ and $14^{\circ} \mathrm{E}$ of the Greenwich Meridian. Adamawa State has an Agro based economy with over $50 \%$ of the populace actively involved in farming either on full time or part time scale (Mishelia et al., 2000). Five experimental sets in triplicate were used for this experiment.

\subsection{Experimental Design}

A factorial design arranged in completely randomized design was used for this experiment. There were five treatments which were replicated thrice making a total of fifteen experimental units.

\subsection{Experimental Set-up}

The experimental set-up was a semi-flow through system consists of fifteen (15) tanks. Twenty fingerlings were assigned to each tanks of 40 liters filled with 30 liters of water.

\subsection{Experimental Fish}

300 fingerlings of Clarias gariepinus was purchased from Modibbo Adama University of Technology Yola, Fisheries Farm and acclimatized at Research Farm. The Clarias gariepinus fingerlings were randomly assigned to each of the fifteen tanks.

\subsection{Preparation of Powdered Samples of Fruits}

Five hundred $(500 \mathrm{~g})$ grams of alligator pepper was cleaned with water to remove foreign particles (such as stone etc.). The samples were subjected to drying process using oven-drying at $70^{\circ} \mathrm{c}$ to obtain moisture ranges between $10-12 \%$. The dried fruits were milled into powder using manual grinding machine (model crown). The powder was further sieved using a $0.45 \mu \mathrm{m}$ sieve aperture. The fine particles obtained from the fruit was packaged using poly ethylene bag for further analysis.

\subsection{Experimental Diets}

Five experimental diets were formulated and prepared for this experiment as shown in the Table 1 Feed ingredients were used to $40 \%$ crude protein. In other diets, alligator pepper meal was included as additive in the following ratio $0 \%, 1.50 \%, 3.00 \%, 4.50 \%$ and $6.00 \%$ and coded of $\mathrm{T} 1, \mathrm{~T} 2, \mathrm{~T} 3, \mathrm{~T} 4$, and $\mathrm{T} 5$ respectively as presented in table 1 . The feed ingredients were fishmeal, soybean meal, groundnut cake, alligator pepper, maize, vitamin premix, salt and palm oil. The various ingredients were grinded to a fine powdered form and thoroughly mixed in a bowl to form a homogenous mixture. Premix and water was added followed by starch as a binding agent. Experimental feeds were pelletized using the mechanical pelletizer, then sundried, labeled and packaged in an air tight bag stored for use thereafter.

\subsection{Feeding and Monitoring}

The fish were staved 24 hours to empty their gastro-intestinal tracts before the commencing of the feeding trials (Eyo, 2004). The experimental fish were fed with 5\% of their body weight per day for 12 weeks. The fish in each tank was batch-weighed weekly throughout the feeding trial using sensitive weighing balance, to determine the feed adjustment based on weight gained. The fish were fed between 8-9am and 5-6pm daily. The fish were monitored for survival by removing the dead fish and recording their numbers. 
Effects of Alligator Pepper (Aframomum Melegueta) Meal Additive Diets on Growth ANS Feed Utilization Clarias Gariepinus (Burchell, 1822)

\subsection{Water Quality Parameters}

The water quality parameters monitored throughout the experiment are temperature, $\mathrm{pH}$, Ammonia and Dissolved oxygen using Boyd (1990) method, being the most important water parameters.

Table1. Ingredient Gross Compositions (g/100) of Experimental Diets

\begin{tabular}{|c|c|c|c|c|c|}
\hline Ingredients & T1 & T2 & T3 & T4 & T5 \\
\hline Soybean & 20.00 & 20.00 & 20.00 & 20.00 & 20.00 \\
\hline Groundnut cake & 15.04 & 15.04 & 15.04 & 15.04 & 15.04 \\
\hline Fishmeal & 20.00 & 20.00 & 20.00 & 20.00 & 20.00 \\
\hline Maize & 39.30 & 36.80 & 34.30 & 31.80 & 29.30 \\
\hline Alligator pepper & $\mathbf{0 . 0 0}$ & $\mathbf{1 . 5 0}$ & $\mathbf{3 . 0 0}$ & $\mathbf{4 . 5 0}$ & $\mathbf{6 . 0 0}$ \\
\hline Oil & 2.00 & 2.00 & 2.00 & 2.00 & 2.00 \\
\hline Vitamin \& Mineral premixes & 0.25 & 0.25 & 0.25 & 0.25 & 0.25 \\
\hline Methionine & 0.50 & 0.50 & 0.50 & 0.50 & 0.50 \\
\hline Lysine & 0.50 & 0.50 & 0.50 & 0.50 & 0.50 \\
\hline Salt & 0.25 & 0.25 & 0.25 & 0.25 & 0.25 \\
\hline Starch & 3.00 & 3.00 & 3.00 & 3.00 & 3.00 \\
\hline Total & 100.00 & 100.00 & 100.00 & 100.00 & 100.00 \\
\hline
\end{tabular}

Keys: $T 1=0.00 \%$ of Alligator pepper; T2=1.50\% of Alligator pepper; $T 3=3.00 \%$ of Alligator pepper; T4 $=4.50 \%$ of Alligator pepper; T5=6.00\% of Alligator pepper

\subsection{Data Collection}

The weight, length and quantity of feds given per each treatment were recorded on weekly basis.

\subsubsection{Growth Performance Parameters}

The following parameters were determined using the weekly weight, length and quantity of feed fed. Weight gain (g/fish), specific growth rate, Relative weight gain, condition factors, feed supplied, feed conversion ratio, and survival following the method of Sogbesan et al. (2017)

\subsubsection{Proximate Composition Determinations}

According to the method described by Pearson and James (2000), the proximate composition which comprises crude protein, crude fibre, carbohydrate, fat, ash and moisture content were determined.

\subsubsection{Statistical Analysis}

The Data on survival rate, weight gain, food conversion ratio and hematological parameter were analyzed statistically using one way analysis of variance (ANOVA) at 5\% probability and Means were separated using LSD. All analysis was done using Graphad Instat Window 10.

\section{RESUlts}

\subsection{Water Quality of the Experimental Diets}

The $\mathrm{pH}$ ranged from $7.3-7.4$, dissolved oxygen, $5.7-7.77 \mathrm{mg} / \mathrm{L}$, Temperature, $25-26.0^{\circ} \mathrm{C}$ and Ammonia, $0.1-0.17 \mathrm{mg} / \mathrm{L}$. There were little fluctuations in the parameters within the different experimental diets. There was a strong positive correlation $r=0.790569 ; \mathrm{p}<0.05$ between dissolved oxygen and ammonia. A negative strong significant correlation $\mathrm{r}=-0.91902 ; \mathrm{p}<0.05$ exits between $\mathrm{pH}$ and dissolved oxygen (table 2).

\subsection{Growth and Feed Utilization of Clarias gariepinus fed Alligator pepper meal Additive diets}

Figure 1 shows the weekly weight of Clarias gariepinus fed each of the experimental diets. Parameters for growth performance and survival rate of Clarias gariepinus are presented in Table 2. A growth performance result varies and differs between fish fed with the control diet and other experimental diets with alligator pepper meal additive diets. Highest mean weight gained of $10.82 \mathrm{~g}$ was recorded in T5 and the lowest mean weight gain of 5.54g was recorded in control diet, T1. Specific growth rate ranged between 0.2088 and 0.4157 . Highest specific growth rate was recorded in $\mathrm{T} 2$ with 0.4157 and the lowest specific growth rate was recorded in T1 with 0.2088 . The highest mean feed intake was recorded in T4 with 33.45 while the lowest was recorded in T2 with 17.80. Highest Protein intake was recorded in T1 with 11.28 while the lowest was recorded in T2 with 7.12. The 
Effects of Alligator Pepper (Aframomum Melegueta) Meal Additive Diets on Growth ANS Feed Utilization Clarias Gariepinus (Burchell, 1822)

highest Protein Efficiency was recorded in T1 with 1.92 while the lowest was recorded in T5 with 1.01.Highest Protein Efficiency Rate was recorded in T1with 1.92 and the lowest Protein Efficiency was recorded in T2 with 0.962 .

Table2. Correlation of the water Parameter measured during the experiment

\begin{tabular}{|l|l|l|l|l|}
\hline & $\mathrm{pH}$ & Dissolved Oxygen & Temperature & Ammonia \\
\hline $\mathrm{pH}$ & & & & \\
\hline Dissolved Oxygen & -0.91902 & & & \\
\hline Temperature & 0.094916 & 0 & & \\
\hline Ammonia & -0.78467 & 0.790569 & -0.35722 & \\
\hline
\end{tabular}

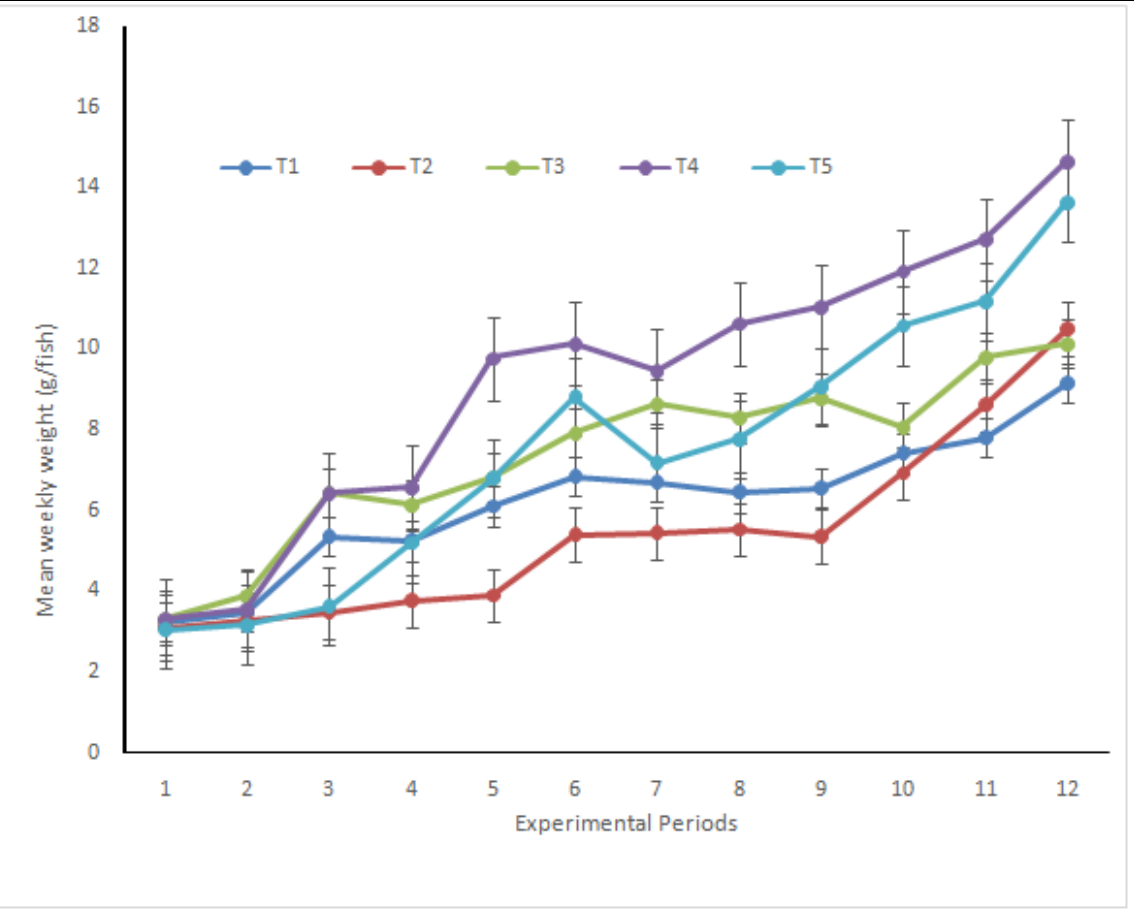

Figure1. Mean weekly weight (g/fish) of Clarias gariepinus fed Alligator Pepper Additive Diets

Table3.Growth and Feed Utilization of Clarias gariepinus fed Alligator Pepper Meal Additive Diets

\begin{tabular}{|c|c|c|c|c|c|}
\hline Indices & $\mathrm{T} 1$ & $\mathrm{~T} 2$ & $\mathrm{~T} 3$ & $\mathrm{~T} 4$ & $\mathrm{~T} 5$ \\
\hline $\begin{array}{c}\text { Initial mean } \\
\text { weight (g/fish) }\end{array}$ & $3.25 \pm 0.1^{\mathrm{a}}$ & $3.09 \pm 0.2^{\mathrm{a}}$ & $3.30 \pm 0.1^{\mathrm{a}}$ & $3.30 \pm 0.1^{\mathrm{a}}$ & $3.05 \pm 0.1^{\mathrm{a}}$ \\
\hline $\begin{array}{c}\text { Final mean } \\
\text { weight (g/fish) }\end{array}$ & $9.14 \pm 0.1^{\mathrm{bc}}$ & $10.49 \pm 0.2^{\mathrm{b}}$ & $10.13 \pm 0.1^{\mathrm{bc}}$ & $14.65 \pm 0.2^{\mathrm{a}}$ & $13.64 \pm 0.2^{\mathrm{a}}$ \\
\hline $\begin{array}{c}\text { Mean weight } \\
\text { gain (g/fish) }\end{array}$ & $5.89 \pm 0.2^{\mathrm{c}}$ & $7.40 \pm 0.1^{\mathrm{b}}$ & $6.83 \pm 0.2^{\mathrm{bc}}$ & $11.35 \pm 0.1^{\mathrm{a}}$ & $10.59 \pm 0.3^{\mathrm{a}}$ \\
\hline $\begin{array}{c}\text { Initial Mean } \\
\text { length (cm) }\end{array}$ & $7.33 \pm 0.2^{\mathrm{a}}$ & $7.33 \pm 0.2^{\mathrm{a}}$ & $7.33 \pm 0.1^{\mathrm{a}}$ & $7.33 \pm 0.2^{\mathrm{a}}$ & $6.33 \pm 0.1^{\mathrm{b}}$ \\
\hline $\begin{array}{c}\text { Final Mean } \\
\text { length (cm) }\end{array}$ & $14.0 \pm 0.3^{\mathrm{c}}$ & $15.0 \pm 0.4^{\mathrm{c}}$ & $17.67 \pm 0.2^{\mathrm{b}}$ & $19.33 \pm 0.5^{\mathrm{a}}$ & $21.17 \pm 0.6^{\mathrm{a}}$ \\
\hline $\begin{array}{c}\text { Relative } \\
\text { growth gain } \\
(\%)\end{array}$ & $168.29 \pm 0.2^{\mathrm{d}}$ & $239.48 \pm 0.3^{\mathrm{b}}$ & $206.97 \pm 0.3^{\mathrm{c}}$ & $343.94 \pm 0.4^{\mathrm{a}}$ & $347.21 \pm 0.2^{\mathrm{a}}$ \\
\hline $\begin{array}{c}\text { Specific } \\
\text { growth rate } \\
(\% / \text { day) }\end{array}$ & $0.5446 \pm 0.01^{\mathrm{d}}$ & $0.6319 \pm 0.02^{\mathrm{b}}$ & $0.5799 \pm 0.01^{\mathrm{c}}$ & $0.7706 \pm 0.03^{\mathrm{a}}$ & $0.7744 \pm 0.02^{\mathrm{a}}$ \\
\hline $\begin{array}{c}\text { Condition } \\
\text { factor (k1) }\end{array}$ & $0.8255 \pm 0.2^{\mathrm{b}}$ & $0.7846 \pm 0.01^{\mathrm{c}}$ & $0.8379 \pm 0.3^{\mathrm{b}}$ & $0.8379 \pm 0.01^{\mathrm{b}}$ & $1.2025 \pm 0.02^{\mathrm{a}}$ \\
\hline $\begin{array}{c}\text { Condition } \\
\text { factor (k2) }\end{array}$ & $0.3331 \pm 0.01^{\mathrm{a}}$ & $0.3108 \pm 0.02^{\mathrm{a}}$ & $0.1836 \pm 0.01^{\mathrm{c}}$ & $0.2028 \pm 0.01^{\mathrm{b}}$ & $0.1116 \pm 0.02^{\mathrm{d}}$ \\
\hline Survival Rate & $70.0 \pm 5.0^{\mathrm{c}}$ & $98.0 \pm 3.0^{\mathrm{a}}$ & $98.0 \pm 2.0^{\mathrm{a}}$ & $95.0 \pm 3.0^{\mathrm{b}}$ & $98.0 \pm 4.0^{\mathrm{a}}$ \\
\hline $\begin{array}{c}\text { Mean Feed } \\
\text { Intake }\end{array}$ & $28.20 \pm 0.5^{\mathrm{b}}$ & $17.80 \pm 0.7^{\mathrm{d}}$ & $21.45 \pm 0.9^{\mathrm{c}}$ & $33.43 \pm 0.8^{\mathrm{a}}$ & $26.75 \pm 0.7^{\mathrm{b}}$ \\
\hline
\end{tabular}


Effects of Alligator Pepper (Aframomum Melegueta) Meal Additive Diets on Growth ANS Feed Utilization Clarias Gariepinus (Burchell, 1822)

\begin{tabular}{|c|c|c|c|c|c|}
\hline $\begin{array}{c}\text { Feed } \\
\text { Conversion } \\
\text { ratio }\end{array}$ & $0.2088 \pm 0.01^{\mathrm{c}}$ & $0.4157 \pm 0.01^{\mathrm{a}}$ & $0.3184 \pm 0.02^{\mathrm{b}}$ & $0.3395 \pm 0.01^{\mathrm{b}}$ & $0.3959 \pm 0.02^{\mathrm{a}}$ \\
\hline Protein Intake & $11.28 \pm 0.1^{\mathrm{b}}$ & $7.12 \pm 0.2^{\mathrm{c}}$ & $8.58 \pm 0.2^{\mathrm{c}}$ & $13.37 \pm 0.3^{\mathrm{a}}$ & $10.70 \pm 0.2^{\mathrm{b}}$ \\
\hline $\begin{array}{c}\text { Protein } \\
\text { Efficiency } \\
\text { Rate }\end{array}$ & $1.92 \pm 0.2^{\mathrm{a}}$ & $0.96 \pm 0.2^{\mathrm{c}}$ & $1.26 \pm 0.2^{\mathrm{b}}$ & $1.18 \pm 0.3^{\mathrm{bc}}$ & $1.01 \pm 0.1^{\mathrm{c}}$ \\
\hline
\end{tabular}

Mean on the same row with different superscripts are significantly different $(p \leq 0.05)$

\section{DISCUSSION AND CONCLUSION}

The water quality parameters monitored throughout the experiment were temperature, $\mathrm{pH}$, ammonia and dissolved oxygen. Most of the parameters were within the tolerable rage. Although there was little fluctuation in the parameters within the different experimental diets. This was due to some variations in the feed intake fish and exposure to sun light. There was a strong positive correlation $\mathrm{r}=0.790569$; $\mathrm{p}<0.05$ between dissolved oxygen and ammonia. Also a negative strong significant correlation $\mathrm{r}=-$ $0.91902 ; \mathrm{p}<0.05$ exits between $\mathrm{pH}$ and dissolved oxygen.

In this study, there was general an increase in weight and length gain in all treatment which indicate that fish were able to covert feed to muscles. Weight gain and growth rate usually considered as the most important measurement of productivity of diets (Hossanin et al. 2003; Omitoyin and Faturoti, 2000). The increased in weight gain recorded in all treatments also indicated that the fish responded positively to all the diets and that the alligator pepper enhance the growth of the fish. The increased in weight gain recorded in all the treatments also indicate that the fish responded positively to all the diets and that Alligator pepper additive diets enhanced the growth of fish. This observation is in agreement with the report of Enemor et al. (2014) that phytochemical such tannin, alkaloid, phytate and saponins increase the growth Rate of animals.

Specific growth rate (SGR) was highest (0.7744) in T5and lowest in T1 with (0.5446), SGR values obtained for diet T2,T3 andT4 were not statistically different but differ significantly from the values obtained for T5 and T1.Mean weight gain is negatively correlated to Mean Feed Intake (MFI) . Feed Conversion Ratio (FCR) are positively correlated to protein efficiency ratio (PER) .The best feed conversion ratio (FCR) is an indication of an of an optimum level of utilization of the diets by fingerlings.

This corresponds with Ahmad et al. (2003) who stated that the lower the FRC, the better the feed utilization by the fish. In this study, the lowest FCR value in an indication of better feed utilization by the fish and this account for better growth performance of $C$. gariepinus feed with Alligator meal additive diet. The correspond with observation made by Shabbier et al. (2003) and Jabeen et al. (2004) in related to situation on feeding trials.

Protein efficiency ratio (PER) is known to be regulate by non-protein energy input of the diet and in a good measures of protein-sparing effect of lipid and carbohydrate (Alaje et al, 2014). PER recoded reworded in this research work exhibited significant difference in all treatment. The significantly higher PER value obtained at T2 indicate maximum utilization of inherent nutrient in the diet of this level which was not in other diet.

The condition factor $\mathrm{K}$ is ranges from 0.1116 to 0.3331 in all treatment, however, the general wellbeing of the fish fed Alligator pepper meal Additive diets one expressed by the condition factor $\mathrm{K}$ which in significantly different from the control. Survival rate was high in all treatment. The higher value $98 \%$ was recorded TS and least $70 \%$ was recorded in $\mathrm{T}_{1}$. The mortality occur in this study might be done to the absents of Alligator peppers in the control $\mathrm{T}_{1}$ diets and some other extraneous factors which agree with Jabeen et al. (2004) who reported that mortality might not be due to the anti-nutrient in the diets alone but also to some other extraneous factor such as tress result from handling

Alligator Pepper as Additive Diets at 1.50, 3.00, 4.50 and 6.00 increased the fish weight gain in all the treatments. This also indicated that the fish respond positively to all the diets and that the alligator pepper enhances the growth of the fish. The increased in weight gain recorded in all the treatments also indicate that the fish responded positively to all the diets and that Alligator pepper additive diets enhanced the growth of fish. 


\section{REFERENCES}

[1] Ahmad, M. S, Ahmed N. (2006). Antiglycation properties of aged garlic extract: possible role in prevention of diabetic complications. Journal nutrition. 2006;136(suppl. 3):796s-799s.

[2] Alaje, D. O., Owolabi, K. T., Olakunle, T. P., Oluoti, O. J. and Adetuberu, I. A. (2014). Nutritional, Minerals and Phytochemicals composition of Garcinia cola (Bitter cola) and Aframomum melegueta (Alligator pepper). IOSR Journal of Environmental Science, Toxicology and Food Technology, 8(1):86.

[3] Boyd, C., (1990). Water Quality. In: aquaculture: farming of Aquatic animals and plants. $2^{\text {nd }}$ edition. Eds. Lucas, J.S. \& Southgate, P.C. John Wiley \& Sons.

[4] Enemor, A., Modie J.A and Ennison, B. (2014). Biological compounds and their functions. Journal of Pharmacy 78-90.

[5] Eyo, A.A. ( 2004). Fundamentals of fish nutrition and diet development an overview.Pp.1-33.In A A.Eyo (ed). National workshop on fish feed development and feeding practices in aquaculture NIFFRI, NewBussa $15^{\text {th }}$ to $19^{\text {th }}$ September,2003.65pp.

[6] Hossanin, M.A.,Nahar, N.,Kamal, and Islam,M.N.(1995).Nutrient digestibility coefficients of some plants and animal proteins for tilapia (Oreochromis mossambicus).Journal Aquaculture in the Tropics, 7;257-266.

[7] Igwe S. A., Emeruwa, I. C. and Modie, J. A. (1999). Ocular toxicity of Aframomum melegueta (alligator pepper) on healthy igbos of Nigeria. Journal of Ethnopharmacology, 65(3):203-205.

[8] Jabeen, S., Salim, M. and Akhtar, P. (2004). Study on feed conversion ratio of major carp (Cirrhinus mrigala) fingerlings fed cotton seed meal, fishe meal barly. Pakistan Veterinary Journal 24(1) 42-26.

[9] Mclaughlin, J.L., Chang. C.J,. and Smith, D.L. (1991). "Bench-top" bioassays for the discovery of bioactive natural products; an update. in: atta-ur-rahman, editor. amsterdam: studies in natural products chemistry, Elsevier Science Publishers; 1991.

[10] Okwu D.E.(2005). Phytochemical and Vitamin content of indigenous spices of Southern Nigeria . Journal of Sustainable Agriculture and. Environment 6(1) 30-37

[11] Omitoyin, B. O. and Faturoti, E. O. (2000): Evaluation of Chicken Offal meal (COM) as protein source for African catfish Clarias gariepinus fingerlings raised in earthen pond. Journal of West African Fisheries IX : 488-495

[12] Pearson, I. and James. R. (2000). Analytical Food Chemistry; methods for analysis In plants.12: 45- 47.

[13] Sogbesan, O.A. (2014). Non-conventional animal protein feedstuffs for the culture of catfish. Publisher Tetfund/ETF, Abuja, Nigeria. Published by Ibadan University Press. 109p. ISBN:978-978-8485-39-1

[14] Sogbesan, O.A., Ahmed, Y.M. and Ajijola, K.O. (2017). Growth Performance. Nutrient Utilization, Somatic Indices and Cost Benefit Analyses of African Basil Leaf Additive Diets on Clarias gariepinus (Burchell, 1822) Fingerlings. Journal of Animal and Nutrition 2(1):10

[15] Spinelli, J. (2007). Evaluating Alternative Protein Source in Aquaculture Diet. National Marine Fisheries, Services, Seattle, Washington, via: www.academicjornals.org/article/ar...

[16] Svobodova, Z., Pravda, D. and Palackova, J. (1991). Unified Methods of Haematological Examination of Fish. Research Institute of Fish Culture and Hydrobiology, Vodnany, Czech Republic, Pages: 31.

[17] Swain, T. (1979). Tannins and lignin in herbivores: their interaction with Plant metabolites, Rosenthal G.A (Eds). Academic press, New York.

Citation: Sogbesan, O.A, et.al, "Effects of Alligator Pepper (Aframomum Melegueta) Meal Additive Diets on Growth ANS Feed Utilization Clarias Gariepinus (Burchell, 1822)", International Journal of Innovative Studies in Aquatic Biology and Fisheries, 6(3), pp. 1-6. DOI: https:// doi.org/10.20431/2454-7670.0603001

Copyright: () 2020 Authors, This is an open-access article distributed under the terms of the Creative Commons Attribution License, which permits unrestricted use, distribution, and reproduction in any medium, provided the original author and source are credited. 